УДК 94(571.1)

ББК 65.3(253.3)

DOI $\underline{10.17150 / 2308-2588.2017 .18(1) .73-99}$

И. М. Савицкий

Институт истории СО РАН, г. Новосибирск, Российская Федерация

\title{
ОРГАНИЗАЦИЯ ВЗАИМОДЕЙСТВИЯ НАУКИ И ОБОРОННОЙ ПРОМЫШЛЕННОСТИ В ЗАПАДНОЙ СИБИРИ В ГОДЫ ВЕЛИКОЙ ОТЕЧЕСТВЕННОЙ ВОЙНЫ
}

Аннотация. В статье рассматривается совершенствование научно-исследовательской работы Академии наук СССР, вузов и наркоматов оборонной промышленности в связи с начавшейся Великой Отечественной войной и перебазированием промышленности на восток страны. В создаваемой здесь главной военно-промышленной базе сосредоточивались производственные мощности, которые в основном обеспечивали Красную армию военной техникой и боеприпасами. Отмечается, что в условиях войны наиболее эффективной формой организации взаимодействия науки и производства стали комиссии, в частности, комиссия АН СССР по мобилизации ресурсов Урала, Западной Сибири и Казахстана для нужд обороны страны, в которую входили ученые не только Академии наук, но и местных вузов, научно-исследовательских учреждений. Помимо этого, научная общественность выступила с инициативой создания для этих целей комитетов ученых и научно-технических советов, которые бы оказывали научно-техническую помощь непосредственно на предприятиях.

Ключевые слова. Великая Отечественная война, оборонная промышленность, наука, ученые, комиссии, комитеты, научно-технические советы. 
I. M. Savitsky Institute of History of SB RAS, Novosibirsk, Russian Federation

\title{
ORGANIZATION OF SCIENCE AND DEFENSE INDUSTRY INTERAGTION IN THE WEST SIBERIA DURING THE GREAT PATRIOTIC WAR
}

\begin{abstract}
The article studies development of research activity of the Academy of Science of USSR, universities, and defense industry departments in connection with the Great Patriotic War and moving of the industrial installments to the East to create new main defense industrial base. The author underlines that commissions like AS USSR Ural, West Siberia, and Kazakhstan resource mobilization commission were the most effective mean of interaction between science and production. Besides that, scientific society initiated creation of committee of scientists and scientific technical boards that provided scientific and technical consulting at the factories.

Keywords. Great Patriotic War, defense industry, science, scientists, commissions, committee, scientific and technical boards.
\end{abstract}

В предвоенные годы Академия наук СССР принимала меры для укрепления связи научных учреждений с оборонно-промышленными наркоматами и их предприятиями. Начавшаяся Великая Отечественная война коренным образом изменила хозяйственную жизнь страны, нарушила дислокацию промышленных предприятий, их экономические связи, обеспечение сырьевыми ресурсами и готовыми изделиями. Но война не дезорганизовала деятельность научных учреждений, лишь во многом изменила направление исследований. 23 июня 1941 г. в АН СССР прошло внеочередное, расширенное собрание Президиума АН, в котором участвовало более 60 видных ученых. Обсуждался вопрос о перестройке науки на военный лад, о помощи ученых Красной армии, промышленности, 
сельскому хозяйству. В принятом решении Президиум предлагал всем отделениям и научным учреждениям АН немедленно пересмотреть тематику и методы исследования, «направив всю творческую инициативу и энергию научных работников, в первую очередь на выполнение задач по укреплению военной мощи нашей Родины» [13, с. 4].

Президиум АН обязал все академические учреждения ускорить завершение научных исследований, результаты которых можно немедленно внедрить в производство. В соответствии с указанием ЦК ВКП(б) в решении Президиума отмечалось, что работа ученых должна проводиться в трех основных направлениях: разработка проблем, имевших оборонное значение и создания средств обороны; научная помощь промышленности в улучшении и освоения производства; мобилизация сырьевых ресурсов, замены дефицитных материалов местным сырьем [2, с. 75]. Аналогичное указание получили вузы и научно-исследовательские учреждения от Всесоюзного комитета по делам высшей школы и отраслевых наркоматов. В качестве приоритетных указывались научная помощь промышленным предприятиям в целях повышения эффективности производства, разработка новых технологий, конструирование и усовершенствование военной техники, вооружения и боеприпасов. На основе принятых направлений научной деятельности президиум АН СССР разработал план первоочередных исследований, в котором содержалось 200 тем, непосредственно связанных с военным производством, обеспечением армии и флота новыми боевыми средствами. План был рассмотрен ГКО и утвержден ЦК партии.

ЦК ВКП(б) внимательно следил за выполнением принятого плана и постоянно предлагал усиливать связи науки с военными организациями. В начале 1942 г. в ЦК состоялось совещание руководителей АН СССР и научно-технических управлений Наркомата 
обороны, на котором обсуждались мероприятия по использованию в вооруженных силах завершенных в институтах работ по военной тематике. Для усиления руководства научной деятельностью в ЦК партии был создан Отдел науки ЦК ВКП(б). Партийным организациям было дано указание активнее привлекать ученых к участию в организации военного производства, всемерно использовать многочисленные научные достижения [7, с. 447-445].

Ученые в конце 1941 г. - начале 1942 г. оказывали помощь предприятиям оборонной промышленности, используя различные формы. Но в первые пять месяцев войны произошло беспрецедентное в мировой практике событие: на восток страны, в основном в Поволжье, Урал и Западную Сибирь, было перебазировано из западных районов 1523 предприятия, преимущественно оборонной и кооперированной с ней промышленности. В Западную Сибирь было эвакуировано 244 завода [4, с. 84]. Учитывая произошедшие изменения в размещении промышленности, Совнарком и ЦК ВКП(б) 16 августа 1941 г. приняли постановление, утвердившее Военно-промышленный план на четвертый квартал 1941 г. и на 1942 г. для районов Поволжья, Урала, Западной Сибири, Казахстана и Средней Азии․․ Планировалось превратить восточные районы в главную военно-промышленную базу страны, создав в Поволжье, на Урале и в Западной Сибири три мощных центра оборонной промышленности, которые и обеспечили бы в основном военной техникой, вооружением и боеприпасами воюющую Красную армию.

По данным Героя Социалистического Труда, академика А. А. Трофимука, для ведения Великой Отечественной войны требовалось примерно 30 видов стра-

${ }^{1}$ Решения партии и правительства по хозяйственным вопросам : [сб. док. за 50 лет] : в 5 т. Т. 3 : 1941-1952 годы. М. : Политиздат, 1968. С. $44-48$. 
тегического сырья. СССР обладал этими ресурсами. А Германия располагала лишь семью, но с захватом стран Европы положение изменилось [14, с. 16]. Для работы предприятий оборонной промышленности нужны были качественные черные и цветные металлы, а их производителям - сырьевые ресурсы, заменители дефицитных материалов, а также новые технологии. В связи с потерей основных предприятий по производству чугуна и выплавке стали, правительство наметило меры по развитию металлургии на востоке страны. В ноябре 1941 г. ЦК ВКП(б) принял постановление «О развитии черной металлургии на Урале и в Сибири в 1942 г.». Был утвержден план расширения производственных мощностей, организации выпуска новых марок чугуна, легированных сталей, брони на металлургических заводах Урала и Сибириㄹ. Уже на второй день войны Кузнецкий металлургический комбинат получил срочное задание организовать новое производство броневой стали и листа.

Важная роль в решении сложных проблем обеспечения предприятий местными сырьевыми ресурсами и в разработке новых технологий принадлежала ученым АН СССР, наркоматов и вузов. Особое место занимала вновь созданная Комиссия АН СССР по мобилизации ресурсов Урала, а с апреля 1942 г. ее деятельность распространялась на Западную Сибирь и Казахстан. 8 мая 1942 г. общее собрание АН СССР утвердило ее состав: председатель - президент АН СССР, академик В. Л. Комаров, заместители председателя - академики И. П. Бардин, Э. В. Брицке, А. А. Байков, С. Г. Струмилин, В. А. Обручев и члены совета. Всего 54 чел. Все руководство работой комиссии в Западной Сибири было возложено на академиков И. П. Бардина и А. А. Скочинского [12, с. 174, 176]. Перед комиссией стояли задачи: оказание научно-технической помощи про-

2 Директивы КПСС и советского правительства по хозяйственным вопросам. Т. 2. М. : Госполитиздат, 1957. С. 724-725. 
мышленности по интенсификации и рационализации производства, увеличению мощностей и выпуска продукции, замены дефицитных и дальнепривозных видов сырья, материалов. В области черной металлургии Западной Сибири входило: обеспечение железной рудой Кузнецкий металлургический комбинат (KMK), разработка баланса металла в Новосибирской области и мероприятия по развитию производства дефицитных видов металла и использования цинкосодержащих железных руд.

Научные исследования вели ученые Комиссии по мобилизации ресурсов Урала, Западной Сибири и Казахстана и под их руководством отраслевые НИИ, Западно-Сибирское геологическое управление, вузы Западной Сибири, в первую очередь Томский университет и Политехнический институт. Перед учеными стояла задача прежде всего расширить местную железорудную базу КМК. К работе комиссии было привлечено около 60 научных учреждений, предприятий и свыше 600 сотрудников вузов, отраслевых исследовательских учреждений, планово-экономических организаций Новосибирска, Томска, Кемерова. Комиссия стала научным штабом, который вместе с Наркоматом черной металлургии работал над созданием железорудной базы для увеличения выплавки металла на востоке страны.

С первых дней войны первостепенное значение имела разведка и добыча тех видов минерального сырья, которые шли на удовлетворение потребностей оборонных отраслей промышленности. Многократно, по сравнению с довоенным периодом, возросла потребность в черных, цветных и редких металлах, легирующих материалах: марганце, хроме, никеле, вольфраме, молибдене и других. Ученые-геологи исследовали Атасуйские месторождения, обладавшие высококачественными рудами, которые были пригодны к плавке без обогащения. Добычу руды в первые годы 
вели открытым способом. Эту группу месторождений, расположенную примерно в 350 км от Карагандинского угольного бассейна, ученые оценили как одну из перспективных баз для развития металлургической промышленности [8, с. 102-103]. В Западной Сибири ускоренно развивались рудники в Горной Шории, Кузнецком Алатау и Хакасии. Поиски стали еще более активными после решения правительства о снабжении КМК собственной рудой. Западно-Сибирским геологическим управлением были подготовлены и переданы в эксплуатацию в 1942 г. Шалымское и Абаканское, а в 1943 г. - Шерегешское и другие месторождения железа [1, с. 263]. В период войны началась добыча марганца на открытых в довоенное годы Дурновском и Мазульском, а во время войны - Усинском месторождении на юге Западной Сибири и Красноярского края, открытом профессором Томского политехнического института (ТПИ) К. В. Радугиным. В 1941-1943 гг. были установлены крупные объемы руды Усинского месторождения и найдены способы получения из нее концентрата, пригодного для ферросплавов. В 1942 г. введен в эксплуатацию один из самых крупных в СССР Кузнецкий завод ферросплавов.

С июня 1942 г. началась разработка открытой Джездинской группы марганцевых месторождений в Казахстане. Всего за 38 дней был построен марганцевый рудник, сооружение которого и разведка месторождения шли одновременно. С вводом его в эксплуатацию восточные районы стали давать 84,6 \% всей добывающей в стране марганцевой руды. В апреле 1942 г. на базе Норильского месторождения начал работать комбинат-гигант, который быстро наращивал темпы производства никеля. В 1940-1941 гг. на юге Казахстана открыто богатое Каратауское месторождение ванадия - самого жаропрочного и тугоплавкого металла, как по запасам, так и по содержанию в ванадиевых рудах таких примесей, как молибден и ко- 
бальт. Это месторождение было крупнейшим в СССР [14, с. 24-25]. В Салаире в 1943-1944 гг. открыто месторождение алюминиевых руд-бокситов, которое стало рудной базой алюминиевой промышленности Сибири. Здесь строился Новокузнецкий алюминиевый завод [1, с. 110]. Предприятиям оборонной промышленности требовалось очень много свинца и цинка. К началу войны были введены в эксплуатацию месторождения в Рудном Алтае и Салаире. Чтобы добиться необходимого прироста производства свинца и цинка комплексная бригада под руководством академика И. П. Бардина и профессора В. И. Смирнова обследовала все предприятия Алтая, Западной Сибири и Восточного Казахстана [9, с. 27].

Работала комиссия по увеличению добычи цветных металлов на Алтае, богатом запасами полиметаллических руд. Здесь были сосредоточены общесоюзные запасы свинца и цинка, а также медных руд, серебра, золота, кадмия, сурьмы и других цветных и редких металлов. Но Алтай давал в начале войны только третью часть свинца и десятую часть меди по сравнению с тем, что мог бы дать по состоянию ресурсной базы. В деятельности по расширению полиметаллической промышленности Алтая приняли участие сотрудники институтов металлургии и горного дела АН СССР, «Гипроцветмета» и комбината «Алтайполиметалл». Они, под руководством академика И.П. Бардина и профессора В. И. Смирнова, тщательно проанализировали состояние каждого предприятия и установили, что основной причиной низкого уровня производства была диспропорция между добычей руды и выплавкой металла. Ученые дали рекомендации по повышению производительности труда на всех предприятиях, позволившие увеличить выплавку в 1943 г. свинца и меди даже при существующем оборудовании и имеющейся сырьевой базе на 20-25 \% выше достигнутого в 1942 г. уровня [8, с. 109]. 
Коренным образом было пересмотрено производство проката черных металлов в сторону качественных его марок, необходимых для выпуска военной техники. В 1942 г. в Кузбассе работала бригада под руководством академика А. А. Байкова, в которую входили академик И. П. Бардин и специалисты Новокузнецкого металлургического института, многое сделавшая для увеличения производства дефицитных марок стали на КМК, разработавшая новые технологические процессы производства легированной стали. Уже в первые годы войны КМК давал около 30 \% всего производства металла в СССР. А за период войны освоил выпуск 80 новых марок стали, в шесть раз увеличил производство качественного проката, в том числе бронированного листа [6, с. 8].

За годы войны геологи Западно-Сибирского геологического управления, научные работники вузов в составе Комиссии АН СССР по мобилизации ресурсов Урала, Западной Сибири, Казахстана и самостоятельно открыли 17 месторождений полезных ископаемых, разведали и передали промышленности для проектирования и эксплуатации 68 месторождений, в их числе 13 месторождений черных металлов, 4 цветных, 3 - редких, 29 - нерудного сырья - формовочных песков, огнеупоров, флюсов для металлургии. Обеспечивали сырьем крупнейшие предприятия Западной Сибири [3, с. 188]. В 1945 г. по сравнению с 1941 г. запасы железной руды увеличились на 355 \%, свинца - на $216 \%$, бокситов - на $2760 \%$, вольфрама - на 140 \% [4, с. 109]. К 1944 г. после снятия остроты сырьевой проблемы, Комиссия АН СССР по мобилизации ресурсов Урала, Западной Сибири и Казахстана на нужды фронта, сыгравшая очень важную роль, прекратила работу.

К началу Великой Отечественной войны в Сибири действовало около 60 вузов, из них 10 технических, а также 80 научно-исследовательских институтов, фи2017. T. 18, № 1. C. 73-99 
лиалов, станций и других подразделений многих отраслей народного хозяйства. Всего в вузах и научных учреждениях было занято 26 тыс. человек [5, с. 101]. Основные научные кадры были сосредоточены в Томске, Новосибирске и Омске. Старейшим и крупнейшим вузом Сибири был Томский университет. Сибирский физико-технический институт (СФТИ) при университете был единственным исследовательским учреждением в Восточной части СССР, разрабатывавшим фундаментальные проблемы в области физики. В его лабораториях профессора В. Д. Кузнецов, А. Б. Сапожников, Н. А. Прилежаева, В. М. Кудрявцев и другие исследовали проблемы, связанные с физикой твердого тела.

Другой старейший вуз Сибири - Томский политехнический институт, входил в десятку крупнейших политехнических вузов страны. Важнейшим научным достижением института являлась, основанная академиками В. А. Обручевым и М. . Усовым школа геологов, представителями которой являлись профессора М. К. Коровин, Ф. Н. Шахов, Ю. А. Кузнецов, А. М. Кузьмин, К. В. Радугин, И. А. Молчанов, А. А. Белицкий, Л. Л. Халфин, изучавшие природные ресурсы. Ученые института также работали над созданием надежной электроаппаратуры (профессор А. А. Воробьев), грузоупорными линиями электропередач (профессор В. И. Щербаков), повышением полезного действия силовых установок (профессор И. Н. Бутаков). Разработкой теории сопротивления материалов занимался профессор А. В. Верховский, вопросами теории и практики резания металлов - профессора А. Н. Добровидов и А. М. Розенберг [11, с. 83, 98, 103].

В группу технических вузов Западной Сибири кроме ТПИ входили - Томский электромеханический институт инженеров транспорта, Сибирский металлургический, Новосибирский институт военных инженеров транспорта, Новосибирский строительный, 
Новосибирский институт инженеров геодезии и картографии, Сибирский автодорожный. В годы войны были основаны Омский и Алтайский машиностроительные институты.

В первые месяцы войны в Западную Сибирь эвакуировано 17 вузов: в Новосибирск -9 вузов, среди них Московский инженерно-строительный, Ленинградский институт точной механики и оптики, Московский и Днепропетровский институты инженеров железнодорожного транспорта, филиал Московского станкостроительного института; в Кемерово - Днепропетровский химический институт, Московский институт стали. Несколько вузов прибыло в Омск и Алтайский край. В результате в 1943/ 44 учебном году в Новосибирской области работало 25 вузов и научно-исследовательских учреждений. В Новосибирске только в 9 вузах было занято 64 профессора - доктора наук, 19 профессоров и около 400 научных работников в звании доцента или имеющих степень кандидата наук ${ }^{3}$. В Омской области действовало 6 вузов. В них работало 384 научных работника, в том числе 58 профессоров и 128 доцентов. В Алтайском крае до войны был один вуз, а в 1944 г. - 7, в которых было занято 179 научных работников, из них 62 профессора. В Томск эвакуировано 300 научных работников [12, с. 280-281].

Также в Новосибирск был эвакуирован Центральный аэрогидродинамический институт (ЦАГИ) с его директором Героем Социалистического Труда, выдающимся ученым, академиком С. А. Чаплыгиным и научными сотрудниками. По данным Т. Н. Осташко, в Новосибирске находилась Военно-инженерная академия с высококвалифицированными учеными и специалистами В. М. Келдышем, И. М. Рабиновичем,

${ }^{3}$ Доблестный труд рабочих, крестьян, интеллигенции Новосибирской области в годы Великой Отечественной войны (19411945): [сб. док.]. Новосибирск : Кн. изд-во, 1964. С. 265, 274.

2017. T. 18, № 1. С. 73-99 
А. А. Гвоздевым [11, с. 79]. В Новосибирск также прибыли научно-исследовательский институт авиационных технологий, Государственный институт мер и измерительных приборов, Северный научно-исследовательский институт гидротехники и мелиорации; в Кемерово - Московский научно-исследовательский институт по безопасности работ в горной промышленности; в Алтайский край - Академия сельскохозяйственных наук им. В. И. Ленина. С ними эвакуированы профессора, доктора и кандидаты наук.

В результате в Западной Сибири было сосредоточено большое число ученых, работающих по различным направлениям науки. Они считали, что для эффективной деятельности необходимо создать организационную структуру для работы на оборону страны. Конкретным ответом научной интеллигенции являлось создание в Западной Сибири комитетов ученых и ученых советов по организации научных работников на службу фронту. В первые дни войны с предложением о создании комитета ученых выступили исследователи Томска: заслуженный деятель науки, лауреат Сталинской премии, профессор В. Д. Кузнецов, известный хирург страны А. Г. Савиных, профессора: Н. И. Карташев, К. Н. Шмаргунов, Б. П. Токин и ряд других ученых города. Патриотическую инициативу ученых 27 июня поддержал Томский горком ВКП(б). Председателем комитета ученых был утвержден профессор Томского университета Б. П. Токин; заместителями председателя - профессора: директор ТПИ К. Н. Шмаргунов, директор СФТИ В. Д. Кузнецов, А. Г. Савиных; членами комитета: Н. И. Карташев, И. Н. Бутаков, И. В. Геблер, М. К. Коровин, В. Н. Кессених, В. Д. Кузнецов. В состав комитета вошло 22 человека, из них 17 профессоров, 3 доцента, бригадный инженер, секретарь горкома партии. Задачей комитета ученых являлась организация ученых города для оказания помощи Красной армии, промышленным 
предприятиям, транспорту и сельскому хозяйству. Комитет ученых, хотя работал на общественных началах, но имел право давать научно-технические и научно-организационные поручения ученым и инженерам ${ }^{4}$.

Деятельность Томского комитета ученых осуществлялась на базе СФТИ. Директор этого института, лауреат Сталинской премии, заслуженный деятель науки, профессор-доктор физико-математических наук писал во Всесоюзный комитет высшей школы, что «огромное большинство работ для заводов и других предприятий по заданию обкома ВКП(б), Комитета ученых, Государственного Комитета Обороны производилось за счет СФТИ и вопрос об уплате труда не поднимался. Институт как госбюджетное учреждение обязан бросить все силы на помощь фронту и не мог встать на путь заключения договоров, как это было в мирное время».

СФТИ был официальным штабом Комитета ученых. В кабинете директора института собирались директора и главные инженеры заводов, профессора томских и эвакуированных вузов. Под руководством В. Д. Кузнецова исследовались проблемы бронепробиваемости. Он лично закончил и сдал в печать 3-й том «Физики твердого тела», являющийся продолжением 2-го тома, удостоенного в 1942 г. Сталинской премии вместе с профессором М. А. Большаниной. В нем заложен фундамент нового направления в области физики твердого тела, имевшего прямое отношение к вопросу о новом скоростном методе анализа бронестойкости, бронепробиваемости и резанию металла 5 . Профессор В. Д. Кузнецов предложил новый метод

4 Томская городская партийная организация в годы Великой Отечественной войны. 1941-1945: сб. док. Томск: Кн. изд-во, 1962. C. 39-61.

5 Государственный архив Новосибирской области (ГАНО). Ф. П-4. ОП. 8. Д. 379. Л. 1, 2. 
испытания брони, позволявший заменить дорогостоящие полигонные испытания брони более дешевыми лабораториями. Он установил ряд закономерностей, в частности, зависимость бронестойкости от механических свойств материалов. Результаты этих исследований обобщил в своей книге «Физика бронебойности». Мастерские СФТИ с высококвалифицированными мастерами - А. И. Рябовым, П. В. Коробейниковым, В. Я. Гуляевым были единственными в СССР, которые по решению ГКО выполняли ответственные задания по изготовлению приборов [12, с. 92].

К В. Д. Кузнецову, как заместителю председателя комитета, приходило много производственников, чтобы проконсультироваться по техническим вопросам, или попросить изготовить в мастерских крайне необходимые детали, штампы, механизмы. Только два дня, взятые из дневниковых записей для примера, 7 и 10 февраля 1942 г. - В. Д. Кузнецов принял и помог в решении ряда вопросов 9 представителям 6 предприятий. Так, директор завода Шарикоподшипников М. И. Эдельштейн и инженер С.В. Пинегин обратились за помощью в изготовлении штампов для сепараторов при производстве подшипников. В дневнике В. Д. Кузнецова стоит запись: «Танки стоят в Сталинграде без подшипников. Для изготовления штампа нужно три токаря на 12 дней. Кроме СФТИ никто сделать не может. Звонил секретарю горкома Тиркунову: как быть, какие заказы оставить, в большом затруднении. Один штамп институт уже сделал. Благодаря ему выпускается 3 тыс. подшипников в день. Все важно, все нужно для фронта, а мастеров не хватает, станков тоже. Завтра решим в горкоме».

Иногда Новосибирский научный совет, не имея в городе специалистов, поступившие запросы пересылал в Томск. Так, СФТИ разработал методику резки оптического стекла без использования алмазных пил. По заданию Новосибирского обкома ВКП(б) и Науч- 
ного совета Томский комитет ученых создал группу химиков до 20 человек для обновления производства химических реактивов около 150 наименований в условиях Новосибирской области. Проблема была полностью решена вплоть до проектирования производства, определения источников сырья, разработки технологии [12, с. 75, 73]. На двух заводах Томска был недостаток алюминиевых сплавов, что могло привести к остановке производства. По заданию Томского комитета ученых профессор М. А. Большанина и ассистент Ю. А. Студенок разработали новую рецептуру сплавов на цинковой основе, которые по механическим свойствам заменили алюминиевые. По заданию оборонных заводов также были разработаны сплавы для замены дефицитной латуни 6 . В рамках технической помощи предприятиям в 1942 г. металлографическая лаборатория СФТИ выполнила сверх плана научно-исследовательские работы по 21 заданию. В списке отчета НИР за 1942 г. институт по заданию Комитета ученых оказал помощь 15 заводам оборонной промышленности, кооперированным с ними предприятиям, в том числе комбинату № 179, заводам № 617, 625, 653, 690, 171, 353, $355,631,673,831,838,266,705$, Томскому подшипниковому, а также многим другим предприятиям Томска и НИИ Западной Сибири, Урала и других регионов страны $[11$, с. 85,86$]$.

В годы войны ученые-геологи индустриального института и университет Томска объединились в геологическое бюро при городском комитете ученых под председательством профессора М. К. Коровина. В его состав входили профессора Ф. И. Шахов, Ю. А. Кузнецов, И. К. Баженов. А в Главгеологии СССР организовано специальное бюро для разработки основных направлений поиска, обобщения результатов разведочных работ сибирской нефти. В Новосибирске создан

${ }^{6}$ Исторический архив. 1959. № 4. С. 76. 2017. T. 18, № 1. С. 73-99 
первый в Сибири специальный нефтеразведочный трест Наркомата нефти. С его организацией расширились масштабы нефтепоисковых работ, развернулись геофизические исследования. Научное консультирование осуществлял профессор М. К. Коровин [10, с. 53].

Ученые из Томска за годы войны на общественных началах внедрили в производство 1607 научных разработок, способствовавших ускорению выпуска оборонной продукции. Важную роль сыграли научные изобретения СФТИ. Только с июня 1941 г. по декабрь 1942 г. они внедрили 20 крупных разработок [12, с. 94]. По инициативе ученых в конце апреля 1944 г. был открыт Дом науки и техники, в котором проводились конференции, семинары и другие мероприятия, имевшие значение для решения научно-технических проблем, подготовки и повышения квалификации кадров.

Эвакуированные в Западную Сибирь промышленные предприятия поставили перед партийными организациями очень сложные задачи. Об этом впоследствии писал в статье «Записки о промышленности», опубликованной в «Правде», первый секретарь Новосибирского обкома ВКП(б) М. В. Кулагин: «Чтобы ввести в действие вновь построенные и эвакуированные предприятия и обеспечить работу промышленности в соответствии с нуждами фронта, необходимо было коренным образом пересмотреть кооперирование заводов, добиться сокращения завоза в область сырья, материалов, полуфабрикатов и других областей» ${ }^{7}$. Решать эти сложные задачи было невозможно без помощи высококвалифицированных специалистов, ученых.

Для реализации этих и многих других сложных проблем, особенно в оборонной промышленности, бюро Новосибирского обкома ВКП(б) и облисполком

${ }^{7}$ Правда. 1942. 30 авг. 
19 июля 1941 г., учитывая деятельность Томского комитета ученых, приняли постановление о создании при Новосибирском облплане Научного совета по мобилизации ресурсов области из 20 чел. Председателем совета утвержден председатель Новосибирского облисполкома И. Т. Гришин; заместителями: В. Ф. Зобнин, А. В. Семин, К. Н. Шмаргунов. В составе совета были в основном профессора вузов, из них 10 из Томска. Все они члены Томского комитета ученых, в том числе председатель Б. П. Токин; новосибирцы: А. Г. Логвиненко, В. М. Мыш, Л. Г. Вайсберг, П. М. Кузнецов, С. М. Островский, Н. И. Жуковский, Н. А. Чинокал, Н. С. Макеров, Майорова, ответственный секретарь совета Г. В. Малкин ${ }^{8}$. О работе совета газета «Советская Сибирь» сообщала, что «свыше 80 профессоров, доцентов, инженеров и экономистов в составе отраслевых бригад делали расчеты производства и потребления более чем 500 видов важнейших полуфабрикатов, материалов, инструмента, необходимых для производства военной техники и боеприпасов ${ }^{9}$. Совет принимал решения по многим другим вопросам экономики.

30 января 1942 г. постановлением бюро Новосибирского горкома ВКП(б) с целью организации научной общественности города и всемерного развития научно-исследовательской работы применительно к требованиям военного времени основан при горисполкоме Новосибирский комитет ученых. Председателем комитета утвержден академик, крупнейший советский ученый в области аэро- и гидродинамики, Герой Социалистического Труда С. А. Чаплыгин; заместителями председателя - заместитель председателя горисполкома А. А. Белоусов, профессор В. И. Раздобреев, доктор медицинских наук В. М. Мыш, профессора: Д. Д. Панов, Н. С. Волков, Г. М. Шахуняну, сельскохозяйственНого института В. Н. Никитин, от-

${ }^{8}$ ГАНО. Ф. П-4. Оп. 59. Д. 97. Л. 55-56.

${ }^{9}$ Советская Сибирь. 1942. 30 авг. 
ветственный секретарь - доцент И. Е. Анфилофьев. Членами комитета избраны - доктор технических наук, Герой Социалистического Труда Н. Н. Поликарпов, члены-корреспонденты АН СССР Г. П. Передерий, М. С. Стрелицкий, В. В. Попов, академик В. А. Леонов, пять профессоров вузов, руководящие работники промышленности, НИИ, партийных и советских органов ${ }^{10}$.

Комитет ученых образовал 13 секций по ведущим отраслям знаний: авиационную, вооружения и боеприпасов, транспортную, энергетики, металлургии, сельского хозяйства, медицинскую, химическую, физическую, стройматериалов, географическую, геологическую, организации производства. Для работы в секциях привлекалось 500 научных работников, не являющихся членами комитета ${ }^{11}$. Комитет установил связи с комитетом ученых Томска и АН СССР, участвовал в ее работе по мобилизации ресурсов Западной Сибири, выполнял ряд заданий комиссий АН СССР.

Специалисты ЦАГИ и завода им. В. П. Чкалова под руководством главного инженера завода А. Н. Тер-Макаряна создали новую прогрессивную технологию производства истребителей ЯК. Особенно значимый вклад внесли академик С. А. Чаплыгин, профессора Н. М. Ветчинкин, Г. Н. Абрамович и инженер М. Ф. Жуков ${ }^{12}$. Научные работники ЦАГИ разработали новую аппаратуру для изучения вибраций и напряжений авиационных конструкций, представляющую существенный шаг вперед по сравнению с имеющимися, в том числе заграничными. Изготовленный комплект аппаратуры показал хорошие результаты и по заказу изготовлялся для заводских лабораторий.

Профессором Аникиным по заданию комиссии АН СССР по выявлению ресурсов Сибири раз-

${ }^{10}$ ГАНО. Ф. П-22. Оп. 31а. Д. З. Л. 190-192.

${ }^{11}$ Советская Сибирь. 1943.7 сент.

${ }^{12}$ ГАНО. Ф. П-4. Оп. 33. Д. 736. Л. 69-73. 
работаны материалы создания в Западной Сибири производственной базы для выпуска сверхтвердых сплавов, абразивных изделий, а также изготовления калиброванной стали. Все это представляло интерес для промышленности боеприпасов. Наркоматом боеприпасов было принято решение по реализации этих предложений ${ }^{13}$.

В области металлургии и металлообработки научными работниками Московского авиационного технологического института (МАТИ), также эвакуированного в Новосибирск, под руководством К. И. Макарова проведена работа по увеличению производительности продольно-строгальных станков. Разработанная ими конструкция резцовой головки позволила повысить производительность станков на 150-175 \%. Проведены исследования высокопрочных алюминиевых сплавов и технологии их изготовления в производственных условиях. Предложены новые составы высокопрочных алюминиевых сплавов для авиационных моторов и самолетов. Новосибирским комитетом ученых осуществлен ряд других работ, имеющих значение для промышленности, но они не были внедрены в производство в годы войны ${ }^{14}$.

По инициативе первого секретаря Новосибирского обкома ВКП(б) М. В. Кулагина летом 1943 г. ученые были привлечены к работе отделов обкома. Бюро обкома поручило комитету ученых организовать активное участие ученых в работе отделов обкома. Для этого было созвано совещание работников отделов и прикрепленных к ним ученых, на котором обсуждались задачи помощи предприятиям ${ }^{15}$.

В МАТИ под руководством профессора Д. Ю. Панова - заместителя председателя Новосибирского комитета ученых была разработана инструкция по

${ }^{13}$ ГАНО. Ф. П-4. ОП. 8. Д. 379. Л. 50-51.

${ }^{14}$ Там же.

${ }^{15}$ Там же. Оп. 68. Д. 83. Л. 32-33. 
ремонту лопастей воздушных винтов в полевых условиях, утвержденная главным управлением ВВС Красной армии и применяемая на фронте. Академик С. А. Чаплыгин, работая в Новосибирске, опубликовал книгу, посвященную новым теоретическим вопросам профилей для скоростных самолетов, имеющую большое значение для повышения скорости боевых машин ${ }^{16}$. В Сибирском инженерно-строительном институте (Сибстрин, Новосибирск) профессор Власов изучил проблему о действии импульса воздушной волны от взрыва фугасных авиабомб на элементы конструкций ${ }^{17}$.

Работники наркоматов и предприятий ответственно относились к запросам фронта. Об этом сообщает в своих воспоминаниях нарком авиапромышленности А. И. Шахурин: «Особенно крупная неприятность на нас обрушилась весной 1943 г., почти за месяц до одной из крупнейших битв Великой Отечественной войны - битвы на Курской дуге. Верховный главнокомандующий И. В. Сталин пригласил нас с наркомом химической промышленности М. Г. Первухиным и дал познакомиться с докладами с фронтов, в которых сообщалось, что на самолетах-истребителях началось массовое коробление фанерной обшивки крыльев, а на некоторых самолетах даже срыв обшивки во время полетов». Этому способствовала плохая погода: то оттепель, то мороз, то дождь, то снег с заморозками. Все самолеты стояли под открытым небом, без каких-либо укрытий, кроме маскировочных. Кроме того, лаки и краски, поставляемые на заводы, были не вполне качественными, включали в себя непроверенные заменители. Но это выяснилось потом, при расследовании, а на момент, когда об этом узнали, причем командующие фронтов сообщали о фак-

${ }^{16}$ Советская Сибирь. 1942. 11 окт.

${ }^{17}$ ГАНО. Ф. П-4. Оп. 44. Д. 54. Л. 71-72.

2017, vol. 18, no. 1, pp. 73-99 
тах непосредственно И. В. Сталину. Он немедленно потребовал ответа.

«Трудно представить, что мы тогда пережили. И только то, что дали слово, что в течение двух недель все будет приведено в полный порядок, как-то его успокоило. Ну, смотрите! - сказал он нам на прощание, хотя знал, что свои обещания мы сдержим». За вторую половину дня и ночь больше чем на десяти заводах, в том числе на Новосибирском авиационном заводе, были организованы ремонтные бригады, возглавляемые инженерами-технологами. Снабженные всеми необходимыми материалами, на самолетах они были доставлены в авиационные части, на фронт. Из наркомата были командированы заместитель наркома, начальник и главный инженер истребительного главка, а также научные работники НИИ авиационных технологий. Нарком химической промышленности М. Г. Первухин лично следил за доставкой на фронт необходимых материалов. В течение 10 дней, даже раньше намеченного срока они доложили в ГКО, что все самолеты приведены в полный порядок. В большей или менышей мере в этом ремонте нуждались несколько сот самолетов [15, с. 101-103].

В первой половине 1944 г. с фронта стали поступать сообщения, что при ударах в башню танков снарядов новейших немецких машин и самоходных орудий выходили из строя прицелы. В результате командировки в воинские части 2-го Украинского фронта главного конструктора и научного работника, эвакуированного в Новосибирск Ленинградского института точной механики и оптики, конструкторы Новосибирского приборостроительного завода разработали новый прицел для тяжелых танков. В отзыве Главного военно-танкового управления Красной армии от 20 декабря 1944 г. отмечается, что прицелы соответствуют техническим требованиям и превосходят по силе оптической системы немецкие танковые прицелы. Завод освоил произ2017. T. 18, № 1. C. 73-99 
водство прицелов в короткий срок, полностью обеспечил потребности армии ${ }^{18}$.

По рекомендации комитета ученых в Новосибирске был открыт Дом науки и техники, который сыграл очень важную роль в развитии связей науки с производством. Только за первый год работы ученые на общественных началах осуществили 465 различных мероприятий, в том числе прочитали 117 курсов, 79 отдельных лекций для инженерно-технических работников, провели 6 конференций, 11 выставок, 23 просмотра технических фильмов, в которых участвовало 234 научных работника, 250 главных инженеров, инженеров и техников, 3600 рабочих ${ }^{19}$.

Почти одновременно с Новосибирским комитетом ученых начал деятельность комитет ученых в крупном промышленном центре Кузбасса - Новокузнецке. 17 февраля 1942 г. прошло совещание в городском комитете партии научных и инженерно-технических работников, а 24 февраля на бюро горкома ВКП(б) было принято решение о создании комитета ученых под председательством профессора П. Г. Рубана и утвержден его состав. Задачей комитета являлась организация научной помощи Кузнецкому металлургическому комбинату и другим промышленным предприятиям научными институтами и отдельными научными работниками в решении различных проблем производства продукции для фронта. На втором заседании 5 марта 1942 г. было решено выделить 30 наиболее важных тем: использование местных марганцевых руд, ускорение доменной плавки, повышение производительности мартеновских печей КМК. Вся тематика работы комитета была разделена на 5 секций: металлургии, электрометаллургии, агломерации, горной геологии и механики. На КМК

${ }^{18}$ ГАНО. Ф. П. 4. Оп. 7. Д. 531. Л. 13-21; Оп. 8. Д. 496. Л. 23-29, 69-70.

${ }^{19}$ Там же. Ф. П-33. Оп. 1. Д. 472. Л. 71; Д. 589. Л. 197. 
коренным образом было пересмотрено производство проката черных металлов для качественных его марок, необходимых для выпуска военной техники. В итоге в 1942 г. в восточных районах СССР было произведено качественного металла на 60 \% больше, чем в 1940 г. в СССР. За первые 2,5 года войны выпуск броневой стали увеличился на 35 тыс. т.

В Кемерове в 1942 г. при горисполкоме также был создан комитет ученых. Основными задачами являлись: разработка новых методов увеличения производственных мощностей и передовой технологии; введение новых методов производства; разработка путей использования местных энергетических и сырьевых ресурсов; оказание помощи рационализаторам и изобретателям на заводах ${ }^{20}$.

В Алтайском крае постановлением крайкома ВКП(б) и крайисполкома от 10 июня 1942 г. был утвержден ученый совет при крайисполкоме. Задачей совета было научное обоснование плана рационального размещения и эксплуатации промышленности, проведение научно-производственных консультаций, осуществление кооперации производства и т. д. Во главе совета был утвержден председатель крайисполкома Н. А. Смердов. 7 сентября 1942 г. при Омском облисполкоме был сформирован научно-технический совет, ориентированный на решение проблем промышленности.

Деятельность комиссии по мобилизации ресурсов Урала, Западной Сибири и Казахстана на нужды обороны страны, широкое участие в ее работе научных работников, объединенных Новосибирским, Томским и другими комитетами ученых региона, способствовали созданию в Западной Сибири филиала АН СССР. Вопрос об организации филиала ставился еще в довоенные годы и был поднят академиками А. А. Скочин-

${ }^{20}$ Кузбасс. 1943.5 февр. 
ским, Л. Д. Шевяковым и обсуждался с местными научными работниками во время их поездки в Кузбасс, а затем в мае 1943 г. был поставлен перед Новосибирским облисполкомом. Только в одной Новосибирской области в это время действовало 15 высших учебных заведений и 19 научно-исследовательских институтов, в которых работало свыше 150 докторов и профессоров и около 200 кандидатов наук. 21 октября 1943 г. было принято решение СНК СССР о создании Западно-Сибирского филиала АН СССР, а в феврале 1944 г. филиал открылся. Его председателем стал академик А. А. Скочинский. Также было принято решение СНК СССР в составе филиала организовать институты: горно-геологический, транспортно-энергетический и медико-биологический ${ }^{21}$.

Филиал создавался как комплексное научно-исследовательское учреждение, призванное всесторонне изучать не только природные ресурсы Западной Сибири, но и координировать деятельность научных учреждений всех областей региона и Красноярского края. В то же время работа филиала и его институтов была направлена на всемерное содействие Красной армии, внедрение в производство научных достижений, оказание научно-технической помощи промышленным предприятиям. В совет филиала входили: академики А. А. Скочинский, В. Л. Комаров - президент АН СССР, Л. Д. Шевяков, В. И. Смирнов, Г. П. Передерий, С. Г. Струмилин, В. Н. Образцов, Н. В. Цицин, члены-корреспонденты: В. И. Вейц, Н. И. Гращенков, Б. К. Шишкин. В состав совета филиала была выдвинута большая группа руководящих партийных и советских работников. В штате институтов филиала в 1945 г. работали один академик, 27 профессоров, 48 кандидатов наук. Среди них - 4 Заслуженных деятеля науки, 3 лауреата Сталинской премии. В 1945 г. в

${ }^{21}$ ГАНО. Ф. П-4. Оп. 150. Д. 230. Л. 19. 
изучении природных ресурсов Сибири работало 13 геологических и одна химическая экспедиций. Одной из важнейших работ, имевших огромное значение, являлось исследование заместителя директора горно-геологического института, заслуженного деятельности науки и техники, профессора-доктора М. К. Коровина о перспективах нефтеносности Западной Сибири. Результаты исследования были одобрены специальным совещанием при президенте Академии наук СССР. На основании ее выводов академик И. П. Бардин обратился к наркому нефтяной промышленности с предложением возобновить поиски и разведку нефти в Западной Сибири, что впоследствии увенчалось открытием богатых запасов нефти [12, с. 195, 203].

Таким образом, в условиях начавшейся Великой Отечественной войны правительство СССР приняло решение перебазировать промышленность, в основном предприятия оборонных отраслей, на восток страны, создать в Поволжье, на Урале и в Западной Сибири главную военно-промышленную базу, способную обеспечивать фронт военной техникой и боеприпасами. Восстановить сотни предприятий, наладить технологию производства, обеспечить их материалами и сырьем невозможно было без квалифицированных специалистов-ученых. Для решения этих проблем АН СССР образовала специальную Комиссию по мобилизации ресурсов Урала, Западной Сибири и Казахстана на нужды обороны страны, в составе которой работали многие, в том числе, выдающиеся ученые, открывшие ряд месторождений черных, цветных металлов и другого сырья, необходимого для производства вооружения и боеприпасов.

Во всех областях региона по инициативе ученых местных и эвакуированных вузов и научно-исследовательских институтов были созданы комитеты ученых, ученые советы, члены которых, в основном на общественной основе, оказывали всемерную помощь пред2017. T. 18, № 1. C. 73-99 
приятиям в решении проблем совершенствования технологии производства, выпуска оборонной техники и боеприпасов. Ученые АН СССР, вузов и НИИ вместе с рабочими, инженерами и техниками ковали оружие Победы над фашизмом.

\section{Список использованной литературы}

1. 50 лет советской геологии. - М. : Недра, 1968. - 420 с.

2. Академия наук СССР - штаб советской науки. - М. : Наука, 1968. - 217 с.

3. Дедюшина Н. А. Вклад ученых Новосибирска в победу над фашистской Германией / Н. А. Дедюшина / / Сибирь в Великой Отечественной войне : материалы конф., посвящ. тридцатилетию Победы в Великой Отечественной войне [1618 апр. 1975 г / редкол. : Б. Н. Волков (отв. ред.) и др.]. - Новосибирск : Наука, 1977. - С. 282-292.

4. Докучаев Г. А. Рабочий класс Сибири и Дальнего Востока в годы Великой Отечественной войны / Г. А. Докучаев. М. : Наука, 1973. - 423 с.

5. Докучаев Г. А. Сибирский тыл в Великой Отечественной войне / Г. А. Докучаев. - Новосибирск : Наука, 1968. - 323 с.

6. Егоров И. В. Ученые Сибири в годы Великой Отечественной войны / И. В. Егоров. - Новосибирск : Кн. изд-во, 1947. - 31 c.

7. История Коммунистической партии Советского Союза : в 6 т. - М. : Политиздат, 1970. - Т. 5, кн. 1. - 724 с.

8. Левшин Б. В. Академия наук СССР в годы Великой Отечественной войны (1941-1945 гг.) / Б. В. Левшин. - М. : Наука, 1966. - 318 c.

9. Левшин Б. В. Советская наука в годы Великой Отечественной войны / Б. В. Левшин. - М. : Наука, 1983. - 383 с.

10. Николаев В. А. Роль Академии наук в изучении нефтегазоносности Западно-Сибирской равнины / В. А. Николаев // Академия наук и Сибирь : 1917-1957 : [сб.] : 60-летию Великой Октябрьской соц. революции посвящается / редкол. : акад. А. П. Окладников (отв. ред.) [и др.]. - Новосибирск : Наука, 1977. - С. 49-62.

11. Осташко Т. Н. Наука и ученые Сибири в годы Великой Отечественной войны / Т. Н. Осташко. - Новосибирск : Издво Новосиб. ун-та, 2002. - 154 с.

12. Петрова Т. Н. Деятельность партийных организаций Западной Сибири по усилению творческого содружества на- 
уки с производством в годы Великой Отечественной войны (1941-1945 гг.) / Т. Н. Петрова. - Томск : Изд-во Томского унта, 1968. - 390 с.

13. Салов В. И. Из истории Академии наук СССР в первые годы Великой Отечественной войны (1941-1943) / В. И. Салов / / Исторические записки. - 1957. - Т. 60. - С. 3-30.

14. Трофимук А. А. Роль геологической науки в минерально-сырьевом и энергетическом обеспечении тыла и фронта в годы Великой Отечественной войны / А. А. Трофимук / / Сибирь в годы Великой Отечественной войны. 40 лет Победы. Новосибирск : Наука, 1985. - С. 15-32.

15. Шахурин А. И. Авиационная промышленность накануне и в годы Великой Отечественной войны / А. И. Шахурин // Советский тыл в Великой Отечественной войне : [сб. ст.] / под общ. ред. П. Н. Поспелова. - М. : Мысль, 1974. Кн. 2. - С. 67-107.

\section{Инфрормация об авторе}

Савицкий Иван Михайлович - доктор исторических наук, главный научный сотрудник, Институт истории СО РАН, 630090, г. Новосибирск, ул. Николаева, 8, е-таil: politik@history.nsc.ru.

\section{Author}

Ivan M. Savitsky - D.Sc. in History, Chief researcher, Institute of History of SB RAS, 8, Nikolaev st., Novosibirsk, Russian Federation, 630090, e-mail: politik@history.nsc.ru.

\section{Библиографическое описание статьи}

Савицкий И. М. Организация взаимодействия науки и оборонной промышленности в Западной Сибири в годы Великой Отечественной войны / И. М. Савицкий / / Историко-экономические исследования. - 2017. - Т. 18, № 1. C. 73-99. - DOI: 10.17150/2308-2588.2017.18(1).73-99.

\section{Reference to article}

Savitsky I. M. Organization of science and defense industry interaction in the West Siberia during the Great Patriotic War. Istoriko-ekonomicheskie issledovaniya $=$ Journal of Economic History \& History of Economics, 2017, vol. 18, no. 1, pp. 73-99. DOI: 10.17150/2308-2588.2017.18(1).73-99. (In Russian). 